\title{
ASEAN Convention on Counter Terrorism (ACCT) in Indonesia: A Paradigm Shift, Issue, Challenges
}

\author{
Siti Azizah ${ }^{1}$, Heryandi $^{2}$, Safira Salsabila Anisa ${ }^{3}$ \\ \{upik.azizah29@gmail.com ${ }^{1}$, heryandi@fh.unila.ac.id², dindasam@gmail.com ${ }^{3}$ \} \\ Universitas Lampung, Lampung, Indonesia ${ }^{1}$, Universitas Lampung, Lampung, Indonesia ${ }^{2}$, \\ Universitas Lampung, Lampung, Indonesia ${ }^{3}$
}

\begin{abstract}
The sea is a strategic route in international trade, so it must be free from the threat of crime such as piracy on ships. Usually, poverty is the driving force behind ship piracy. In 2016, there were 3 times the hijacking of Indonesian-flagged vessels in Philippine waters carried out by terrorist groups. This is the background for the formation of cooperation between ASEAN leaders known as the ASEAN Convention on Counter Terrorism (ACCT), the convention on the fight against terrorism. The purpose of this paper is to examine the arrangement of ship piracy in the waters of the Philippines and Indonesia based on the ASEAN Convention on Counter Terrorism (ACCT). Efforts to deal with and prevent piracy from ships which must be carried out by the Philippines and Indonesia are based on ACCT, which are contained in Article 6 of ACCT. However, only a few points were implemented by the Philippines and Indonesia, namely: points a, b, c, $\mathrm{d}, \mathrm{e}, \mathrm{g}, \mathrm{h}$, and $\mathrm{m}$. In addition, member states must resolve disputes peacefully in the event of differences in interpretation or application of the provisions in the ACCT.
\end{abstract}

Keywords: ASEAN Convention on Counter Terrorism (ACCT), Piracy, Terrorist

\section{Introduction}

The sea is the water that connects a land area with other land areas, can connect the land area within a country, between countries, and between continents. The sea has biodiversity and non-biodiversity that must be preserved. In addition, the sea is a strategic route in international trade that must be protected from various forms of crime. The sea must be a safe area for all forms of activity in it and free from various threats of ration, one of which is piracy against ships[1]. However, if there are still threats in the form of violence, terrorism, and piracy of ships, both on a national and international scale, then the sea cannot be said to be a safe water area.

Based on Article 101 of the 1982 Law of the Sea Law [2], it is explained that terrorist attacks in the form of ship hijacking, have restrictions on the definition as read:

"Piracy at sea consists of one of the following actions:

a. Any act of violence or illegal detention, or any act of destruction, which is carried out for personal purposes by the crew or passengers of a private ship or aircraft, and is shown:

1) on the high seas, on ships or other aircraft or on persons or goods that are aboard such ships or aircraft;

2) on a ship, aircraft, person or item in a place outside the jurisdiction of any country;

b. Every action participates voluntarily in the operation of a ship or aircraft by 
knowing the facts that make a ship or aircraft hijacked.

c. Every action invites or intentionally helps the action mentioned in sub- paragraph (a) or (b). "

In addition to these provisions, another source of law regarding piracy is contained in the 1988 Rome Convention which regulates the Suppression of Unlawful Act.

Against the Safety of Maritime Navigation. The background to the birth of this Convention is the violation of the law on the safety of maritime navigation which endangers the safety of people and their property, and damages the image of maritime navigation. Based on this, the Convention has 22 Articles which clearly regulate the eradication of illegal actions that endanger the safety of maritime navigation, and regulates dispute resolution that can be carried out by negotiation. However, if this cannot be resolved by negotiation, one of the parties can submit it to the International Court of Justice for settlement.

The poverty factor is the driving force for ship piracy in strategic waters in international trade, one of which is Indonesia. Indonesia has become a strategic trade channel in the development of the ASEAN Economic Community (AEC) which is a form of economic integration in the Southeast Asian region. MEA has a goal to realize a single market based on production, with capital flows, investments, goods and services that are increasingly free in the Southeast Asian region [3]. Therefore, there is a concern for ASEAN countries, especially Indonesia, which will hijack ships that can endanger and harm economic activities. ASEAN countries work together to eradicate piracy actions to address this through the ASEAN Security Community (ASC); ASEAN Ministerial Meeting on Transnational Crime; The Asean Center for Combating Transnational Crime (ACTC); and the ASEAN Regional Forum (ARF). However, these agencies have not been able to deal with ship piracy significantly, so there are still many cases of ship hijacking that occur.

In 2016, there were 3 times the hijacking of Indonesian-flagged vessels in the Philippine territorial waters carried out by the terrorist groups, as follows:

1. Hijacking of ship 2 carrying 7000 tons of coal to the Puting River, South Kalimantan Batangas, South Philippines. The ship was a Brahma 12 ship and Anand 12 ship, 10 crew members (ABK) were held hostage by asking for a ransom of IDR. 60,000,000,000 (SixtyBillion Rupiah) [4].

2. Hijacking of the Henry TB Tug and the Cristi barge sailing from Cebu, Philippines to Tarakan, North Kalimantan in the border region between the Philippines and Malaysia. This hijacking caused one crew member to be shot, 4 people kidnapped [5], by asking for a ransom of IDR. 14,000,000,000 (fourteen billion rupiah) and only able to save four people [6].

3. Piracy of 2 vessels owned by PT. The Rusianto Brothers, namely the ships Tugboat Charles 001 and Robby 152 that sailed carrying coal from Tagoloan Cagayan, Mindanao, to Samarinda, East Kalimantan, in the Sulu Sea, Southwest of the Philippines. 2 of the ships were taken hostage by the terrorist group Abu Sayyaf by asking for a ransom of around IDR. 65,000,000,000 (Sixty-five billion Rupiah) for 7 crew members taken hostage [7]. This piracy also became the third piracy that occurred in Tawi-Tawi international waters (border of the Philippines - Sabah, Malaysia) in the last month [8].

This is the background of the formation of collaboration among ASEAN leaders known as the ASEAN Convention on Counter Terrorism (ACCT), which is a formulation of the law or the Convention concerning the fight against terrorism. This convention was adopted at the 
12th ASEAN Summit, 13 January 2007, in Cebu Philippines [9]. This convention has the objectives stated in Article 1 of ACCT, which reads: "This convention will provide a regional cooperation framework to eradicate, prevent and stop terrorism in all its forms and manifestations, and to strengthen cooperation between law enforcement agencies and relevant authorities of the Parties in combating terrorism."

Based on these objectives, this Convention provides an international legal guarantee that is in line with national legal regulations in the territory of a country, justice, and the fulfillment of global human rights, for every person who is detained or gets other actions from the legal process provided for in this Convention.

Before the establishment of the ASEAN Convention on Counter Terrorism (ACCT), ASEAN had already formed the ASEAN Maritime Forum (AMF) which was affirmed in the ASEAN Concord II (Bali Concord II), 7 October 2003, in Bali, Indonesia. This meeting discussed the issue of maritime which must be resolved regionally and professionally. Then discussions on maritime issues continued at the first AMF meeting on 28-29 July 2010, in Surabaya, Indonesia [10].

Piracy hijacking by terrorist groups is a form of crime that disturbs security and world peace, moreover the current case of hijacking Indonesian-flagged vessels in Philippine waters is a threat to peace and security in the Southeast Asian region, so it is necessary a preventive and strict legal mechanism is carried out to follow up on the crime of hijacking the ship. Furthermore, no less important is ASEAN's role as a regional organization which is the umbrella of peace in the countries of Southeast Asia to resolve cases between Indonesia and the Philippines, through cooperation and legal mechanisms.

Based on Article 2 Paragraph (1) of the ASEAN Convention on Counter Terrorism (ACCT) which is guided by the 1988 Rome Convention, Article 3 Paragraph (1) states that crime is:

a) Seize or exercise control of the ship by force or threats or other forms of intimidation; or

b) Performing acts of violence against people on board the ship if actions that might jeopardize the safety of the navigation of the ship; or

c) Destroying the ship or causing damage to the ship or its cargo which is likely to endanger the safe navigation of the ship; or

d) Place or cause to be placed on the ship, in any way, device or substance which is likely to destroy the ship, or cause damage to the ship or its cargo which is dangerous or might jeopardize the safe navigation of the ship; or

e) Destroying or seriously damaging maritime navigation facilities or seriously disrupting their operations, if any of these actions might jeopardize the safe navigation of the ship; or

f) Communicating information that he knows is false, thus jeopardizing safe navigation from the ship; or

g) Injuring or killing people, in connection with a commission or commission of attempted criminal offenses specified in sub-paragraphs (a) to (f).

Based on this background, an analysis is needed on "Judicial Studies of Piracy in Philippine and Indonesian Seas based on the ASEAN Convention on Counter Terrorism (ACCT)". The issue to be discussed is how arrangement of ship piracy in the waters of the Philippines and Indonesia based on the ASEAN Convention on Counter Terrorism (ACCT)? 


\section{Methods}

The type of research used is normative legal research, which is research carried out by examining data obtained by conventions and applied to specific legal issues, [11] in this study refers to international law. The object of this research is a document of conventions and library materials which the researcher hopes can formulate and formulate research problems appropriately. The data collection method used is library research. Library research is a series of activities carried out by the author to obtain secondary data by reading, taking notes, quoting from various literature, regulations, books, mass media and other written legal materials that have to do with the research carried out. The data analysis method used is qualitative analysis, which describes in detail in words to form a sentence description that will describe and explain the research results obtained by the author so that they can be understood. Data analysis was carried out after processing the data, which started with reading all the sources and then studied and analyzed.

\section{$3 \quad$ Result and Discussion}

The Charter of the United Nations (UN) serves as a guideline for ASEAN in maintaining world peace and security in general, and Southeast Asia in particular. ASEAN always cooperates in creating peace and security, one of which is through eradicating acts of terrorism in the territorial waters of the Southeast Asian region. Boat piracy is said to be one of the acts of terrorism because it contains elements of threat, scare, hostage taking, and violence that causes death, to other citizens who cross or are in the territory of the terrorist country or the territory of the country where the hijackers are. This is in line with the notion of terrorism in the ASEAN Convention on Counter Terrorism (ACCT), and the definition contained in the 1988 Rome Convention concerning the eradication of illegal acts against maritime navigation safety.

As stated at the opening of ACCT, which states that: "ASEAN is paying close attention to the serious dangers posed by terrorism against innocent people, infrastructure and the environment, regional and international peace and stability, and economic development" [12]. In order to bring about peace in the Southeast Asian region, ASEAN has established a legal instrument that can combat terrorism in territorial waters in the form of ship hijacking, through the ASEAN Convention on Counter Terrorism (ACCT).

This convention was signed at the 12th ASEAN Summit, January 2007, in Cebu, Philippines. Indonesia acted as Lead Shepherd in spearheading the formation of ACCT and combating terrorism in Southeast Asia at the meeting. This convention provides a very comprehensive legal certainty (prevention, enforcement and rehabilitation) in eradicating terrorist acts in ASEAN (Dian, 2008). The crime of terrorism is a transnational crime that can cause many lives lost without seeing the background of the victim, causing fear in the wider community, as well as property losses. Therefore we need a way to eradicate terrorism through regional cooperation. The ASEAN Convention on Counter Terrorism is expected to realize an ASEAN region that is safe from acts of terrorism, especially ship hijacking.

Article 6 of the ASEAN Convention on Counter Terrorism (ACCT) explains the cooperation carried out by ASEAN in combating crime, but not all have been carried out by Indonesia and the Philippines as in point a which reads: "Take the necessary steps to prevent the commission of terrorist acts, including by the provision of early warning to the other Parties through the exchange of information." The actions taken by Indonesia and the 
Philippines in preventing acts of terrorism are to exchange information.

Indonesia and the Philippines have implemented points $b^{3}$ and $c^{4}$ by regulating the prevention and actions given to donors and / or facilities for acts of terrorism in Article 11 of Law Number 15 Year 2003 and Article 4 of the Republic Act Number 9372 regarding 40 years imprisonment for cooperation for terrorism.

Indonesia has also implemented point $\mathrm{d}^{5}$ by conducting patrols at the border by all Navigation District Heads in accordance with the orders of the Director General of Sea Transportation Tonny Budiono. This was done by monitoring the Coastal Operations Radio Station and increasing security by all Marine and Coastal Guard (PLP) bases and guarding and patrolling by the entire fleet [7].

Point $\mathrm{e}^{6}$ has been implemented by member countries including Indonesia and the Philippines with cooperation between the Ministry of Foreign Affairs and Malaysian and Philippine authorities [5]. In addition, Indonesia, Malaysia and the Philippines also held a regional meeting on 5 May 2016 in Yogyakarta. This meeting discussed the security of waters against hijacking of ships by armed extremist groups on the borders of the three countries [13].

The application of point $\mathrm{g}^{7}$ has also been carried out with the signing of the Exclusive Economic Zone or EEZ agreement in Jakarta on July 15, 2013 between Indonesia and the Philippines, represented by the Indonesian Minister of Foreign Affairs, Marty Natalegawa and the Philippine Foreign Minister Albert F. Del Rosario [14].

Indonesia and the Philippines have also implemented point $\mathrm{h}^{8}$ with the signing of the agreement on water security on July 14, 2016 at Park Lane Hotel Jakarta. This agreement was signed by Indonesia, Malaysia and the Philippines, represented by the Operations Assistant to the Commander of the TNI, Deputy Chief of Staff for Operations of the Armed Forces of the Philippines and Deputy Secretary of Maritime Security and the Sovereignty Division of the Malaysian Prime Minister's National Security Council. The purpose of this agreement is to protect and strengthen the security of the territorial waters of each country to improve communication, as well as exchange information and intelligence [15].

Point $\mathrm{m}^{9}$ has been implemented by Indonesia and the Philippines, which is contained in Article 25 paragraph (1) of Law Number 15 Year 2003 Chapter V concerning Investigations, Prosecutions, and Investigations at the Trial Court which reads: "Investigations, prosecutions, and hearings in court hearings in criminal acts of terrorism are carried out under the applicable procedural law, unless otherwise stipulated in the Government Regulation in lieu of this law."

The Philippines also regulates it in Article 51, which reads: "The police or law enforcement officers to whom the name of a suspect in the crime of terrorism was first revealed shall record the real name and the specific address of the informant." In terms of the two articles, the parties involved in terrorism in any form will be brought to trial.

The obligation of ASEAN members is to make effective the application of the provisions contained in this convention. Member countries have the obligation to take action in accordance with ASEAN Charter Article 5 Paragraph (2) which confirms that: "Member States shall take all necessary measures, including the enactment of appropriate domestic legislation, to effectively implement the provisions of this Charter and to comply with all obligations of membership."

Member states are required to establish their own jurisdiction in dealing with crimes contained in Article 2 of ACCT. Indonesia and the Philippines have implemented this matter with the enactment of Law Number 15 of 2003 and Republic Act Number 9372. The obligation is affirmed in Article 7 Paragraph (1) of ACCT, which reads: "A Party shall take 
such measures as may be necessary to establish its jurisdiction over the offenses covered in Article II of this Convention ..."

The state also has an obligation to provide equal treatment to anyone who is detained or subject to other actions in accordance with applicable regulations as described in Article 8 Paragraph (1) ACCT, namely: "Any person who is taken into custody or regarding whom any other measures are taken or proceedings are carried out pursuant to this Convention shall be guaranteed fair treatment, including enjoyment of all rights and guarantees in conformity with the laws of the Party in the territory of which person is present and applicable provisions of international law, including international human rights law."

After receiving a report regarding the perpetrators suspected of having committed a crime, the local authorities have the obligation to investigate the truth of the information as stated in Article 8 paragraph (2) of the ACCT which reads: "... the Party concerned shall take such measures as may be necessary under its domestic laws to investigate the facts contained in the information."

Local authorities who have the authority to act against perpetrators or suspects have an obligation to take steps in the process of prosecution or extradition in accordance with the regulations of their country. This is explained in Article 8 paragraph (3) of the ACCT which reads: "... shall take the appropriate measures under its domestic laws so as to ensure that one's presence for the purpose of prosecution or extradition.

Member states have an obligation to take measures to ensure that piracy is wrong. Member countries are also obliged to prevent piracy by providing information exchange facilities in the form of establishing communication channels between authorized agencies as stated in Article 9 of ACCT which reads:

1. The Parties shall adopt such measures as may be necessary, including, where appropriate, national legislation, to ensure that offenses are covered in Article II of this Convention, especially when it is intended to intimidate a population, or to compel a government or an international organizations to do or to abstain from doing any act, are under no circumstances justifiable by considerations of a political, philosophical, ideological, racial, ethnic, religious or other similar nature.

2 Pursuant to Article VI of this Convention, the Parties shall, where possible, establish channels of communication between their competent agencies to facilitate the exchange of information to prevent the commission of offenses covered in Article II of this Convention.

Member states have an obligation to exchange experiences about the rehabilitation program of parties involved in acts of terrorism, as explained in Article 11 of the ACCT which reads: "The Parties shall endeavor to promote the sharing of best practices on rehabilitative programs ..."

Member countries are also required to provide assistance with piracy investigations in order to carry out properly as stated in Article 12 Paragraph (1) ACCT: "The Parties shall, in conformity with their respective domestic laws, are afforded the widest measure of assistance in connection with investigations or criminal proceedings brought in respect of the offenses covered in Article II of this Convention."

Member countries are obliged to hand over pirates to the authorities for immediate prosecution of suspects without exception as explained in Article 13 ACCT, which reads:

1. The Party in the territory of which the alleged offender is present shall, in cases to which Article VII of this Convention applies, if it does not extradite that person, be obliged, without exception whatsoever and whether or not the offence was committed in its territory, to submit the case without undue delay to its competent authorities for 
the purpose of prosecution, through proceedings in accordance with the domestic laws of that Party. Those authorities shall take their decisions in the same manner as in the case of any other circumstances of a grave nature under the domestic laws of that Party.

2. The offences covered in Article II of this Convention shall not be deemed to be included as extraditable offences in any extradition treaty existing between any of the Parties before the entry into force of this Convention. The Parties undertake to include such offenses as extraditable offences in every extradition treaty to be subsequently concluded between them.

If there are differences or disputes between member states that result from the interpretation or application of the provisions in the ACCT, the dispute must be resolved peacefully by means of consultation and negotiation between parties through "Any difference or dispute between the Parties arising from the interpretation or application of the provisions of this Convention shall be settled amicably through consultation and negotiation between the Parties through diplomatic channels or any other peaceful means for the settlement of disputes as agreed upon between the Parties"

In addition, according to ACCT, settlement efforts can also be made through rehabilitation, extradition, or in accordance with the jurisdiction of the country.

\section{Conclussion}

Based on the provisions contained in Article 7 Paragraph (1) of the ASEAN Convention on Counter Terrorism (ACCT), the Philippines and Indonesia have their own arrangements regarding piracy of ships, namely Law Number 15 of 2003 and Republic Act Number 9372. In addition, to handle and prevent piracy, the Philippines and Indonesia have also applied the provisions in accordance with the provisions contained in Article 6 of ACCT. However, only a few points have been implemented by the Philippines and Indonesia, namely:

1. point a by exchanging information between Indonesia and the Philippines to prevent the occurrence of acts of terrorism especially in hijacking ships;

2. points $\mathrm{b}$ and $\mathrm{c}$ by regulating the prevention and actions given to donors and/or facilities for acts of terrorism in Article 11 of Law Number 15 Year 2003 and Article 4 of the Republic Act Number 9372 concerning 40 years imprisonment for cooperation for terrorism;

3. point $\mathrm{d}$ by conducting patrols at the border by all Navigation District Heads in accordance with the orders of the Director General of Sea Transportation Tonny Budiono.

4. Point e by conducting cooperation and regional meetings between the Ministry of Foreign Affairs and Malaysian and Philippine authorities.

5. Point $g$ with the signing of the Exclusive Economic Zone or EEZ agreement in Jakarta on July 15, 2013 between Indonesia and the Philippines represented by the Indonesian Minister of Foreign Affairs, Marty Natalegawa and the Philippine Foreign Minister Albert F. Del Rosario.

6. point $\mathrm{h}$ with the signing of the agreement on waters security on July 14, 2016 at Park Lane Hotel Jakarta by Indonesia, Malaysia and the Philippines represented by the Operations Assistant to the Commander of the TNI, Deputy Chief of Staff for Operations of the Armed Forces of the Philippines and Deputy Secretary of Sea Security and Malaysian Prime Minister's National Security Council Sovereignty 
Division.

7. Point $\mathrm{m}$ has been carried out by Indonesia and the Philippines, that is in accordance with Article 25 paragraph (1) of Law Number 15 Year 2003 Chapter V concerning Investigations, Prosecutions and Examinations at the Trial Court and in Article 51 of the Philippine arrangements.

Indonesia and the Philippines also have the obligation to provide equal treatment to parties who are detained or subject to other actions in accordance with applicable regulations as described in Article 8 Paragraph (1) ACCT. In addition, after receiving a report regarding the perpetrators suspected of having committed a crime, the local authorities who have the obligation to investigate the truth of the information as confirmed in Article 8 paragraph (2) ACCT. The local party authorized to act against the perpetrators or suspects has the obligation to take steps in the process of prosecution or extradition in accordance with the regulations of their country as explained in Article 8 paragraph (3) ACCT.

Member countries including Indonesia and the Philippines have an obligation to exchange experiences with the rehabilitation programs of parties involved in acts of terrorism, as explained in Article 11 of ACCT. Member countries are also required to provide assistance in the investigation of piracy so that it can be carried out properly as stated in Article 12 Paragraph (1) ACCT. In addition, member countries are also required to hand over piracy to the authorities for immediate prosecution of suspects without exception as explained in Article 13 of ACCT.

If there are differences or disputes between member states that result from the interpretation or application of the provisions in the ACCT, the dispute must be resolved peacefully by means of consultation and negotiation between parties through diplomatic channels or other peaceful means in accordance with the agreement of the relevant parties such as those described in Article 19 of ACCT regarding dispute resolution. According to ACCT, settlement efforts can also be made through rehabilitation, extradition, or in accordance with the jurisdiction of the country.

\section{References}

[1] Wira Yudha Nugraha, "Tinjauan Yuridis Tentang Perompakan Kapal Laut Di Perairan Somalia," Universitas Sumatera Utara, 2012.

[2] United Nations Convention on the Law of the Sea. 1892

[3] D. Siswaningsih, Peluang dan Tantangan Indonesia Pasar Bebas ASEAN Masyarakat Ekonomi ASEAN (MEA), Edisi Janu. Jakarta: Warta Ekspor, 2015.

[4] "Panglima TNI Ungkap Motif Pembajakan Kapal oleh Abu Sayyaf," Tempo. https://m.tempo.co/read/news/2016/03/30/078758151/panglima-tni-ungkap-motif- pembajakankapal-oleh-abu-sayyaf. (accessed Jun. 22, 2020).

[5] Eva Mazrieva, "Lagi Dua Kapal Indonesia Dibajak,” VOA Indonesia, 2016. http://www.voaindonesia.com/a/lagi-dua-kapal-indonesia-dibajak-/3288050.html (accessed Jun. $22,2020)$.

[6] "Berita Hari Ini Kronologi Abu Sayyaf Bajak Kapal Indonesia 10 WNI Dijadikan Sandera dan Minta Tebusan," Newsth, 2016. http://www.newsth.com/ruptik/11575/berita-hari-ini-kronologiabu-sayyaf-bajak- kapal-indonesia-10-wni-dijadikan-sandera-dan-minta-tebusan/ (accessed Jun. 23, 2020).

[7] P. Gumilang, "Pembajakan di Filipina Indonesia Taruh Tentara dalam Kapal," CNN Indonesia, 2016. http://www.cnnindonesia.com/nasional/20160702052225-20-142559/pembajakan-difilipina-indonesia-taruh-tentara-dalam-kapal/ (accessed Jun. 23, 2020).

[8] Anri Syaiful, “Kapal Indonesia Dibajak di Perairan Filipina, 4 WNI Diculik,” Liputan 6, 2016. http://news.liputan6.com/read/2484913/kapal-indonesia-dibajak-di-perairan-filipina- 4-wni- 
diculik. (accessed Jun. 23, 2020).

[9] "No Title," UPN Yogyakarta. http://repository.upnyk.ac.id/3838/1. (accessed Jun. 25, 2020).

[10] "1st Meeting Of Asean Maritime Forum (AMF)," Ministry of Foreign Affairs Republic of Indonesia, 2010. .

[11] A. Soejono., Metode Penelitian Hukum. Jakarta: Rineka Cipta, 2003.

[12] ASEAN Convention on Counter Terrorism (ACCT). .

[13] A. DH, "Filipina Dukung Upaya Kerja Sama Atasi Pembajakan Kapal 8Gz," Tirto.id, 2016. https://tirto.id/filipina-dukung-upaya-kerja-sama-atasi-pembajakan-kapal-8Gz. (accessed Jun. $26,2020)$.

[14] "Indonesia dan Filipina Tegaskan Komitmen Perkuat Kerja Sama Bilateral yang Lebih Produktif," Ministry of Foreign Affairs Republic of Indonesia, 2014.

[15] Fabian Januarius Kuwado, "Militer Indonesia, Filipina, dan Malaysia Sepakat Respons Cepat Pembajakan Kapal," Kompas.com, 2016.

http://nasional.kompas.com/read/2016/07/15/18191381/militer.indonesia.filipina.dan. malaysia.sepakat.respons.cepat.pembajakan.kapal. 